\title{
Production Potential and Economic Feasibility of Mustard - Based Intercropping System with Chickpea and Lentil Crops under Rainfed Condition
}

\author{
Sumit Raj* and S.K. Uttam \\ Department of Soil Conservation and Water Management, C.S. Azad University of Agriculture \\ and Technology, Kanpur (U.P.), India \\ *Corresponding author
}

\section{A B S T R A C T}

Keywords

Land equivalent ratio, Water use efficiency, Weed dynamics, Net return, $\mathrm{B}: \mathrm{C}$ ratio, Mulch

Article Info

Accepted:

15 October 2020

Available Online:

10 November 2020
A field experiment was conducted during the rabi seasons of 2016-17 and 2017-18 at Students Instructional Farm of the C.S. Azad University of Agriculture and Technology, Kanpur to find out the effect of cropping systems and mulches on yield, LER, total water use, WUE and economics of crops under rainfed condition. Results obtained that the yield of individual crop depressed in additive intercropping where depression was more in lentil than chickpea. The yields of mustard, chickpea and lentil were highest in their sole stands. The yield of chickpea and lentil in terms of mustard equivalent seed yield showed highest significant production in row crop adjustment of mustard + chickpea $(1+1)$ additive series. Moreover, the LER, WUE, net return and B:C ratio were also highest found to be the remunerative. Soil dust mulch created by weeding and hoeing at 25 DAS resulted higher mustard equivalent seed yield, LER, WUE and net return than without dust mulch plot.

\section{Introduction}

During rabi where crops are raised on receding conserved moisture, the crop productivity is greatly determined, along with a number of other factors, by the crop and its variety as well as cropping system including mixed or intercropping. In intercropping, the plant density of base crop is maintained and its optimum and additional population of intercrop is pushed for better use of resources (Das et al., 2017; Meena and Kumhar, 2017; Hasan et al., 2018 and Yadav et al., 2018). Results of an intercropping experiment where intercropping of chickpea and lentil in different proportions with mustard as base crop, have been compared to total productivity, water use efficiency and net return. 


\section{Materials and Methods}

A field experiment was conducted during rabi seasons of 2016-17 and 2017-18 at Students Instructional Farm of C.S. Azad University of Agriculture and Technology, Kanpur. The soil of experimental field was deep, well drained, sandy loam in texture and slightly alkaline in nature with low status of organic carbon and total-N content. It was medium in available $\mathrm{P}_{2} \mathrm{O}_{5}$ and $\mathrm{K}_{2} \mathrm{O}$. Electrical conductivity was found almost normal. Other soil properties were also found almost normal as per sandy loam texture of experimental soil. 9 cropping systems and 2 mulch practices were tested in the experiment (Table 1, 2 and 3). The treatments were replicated thrice in a Split plot design, keeping the cropping systems in main plots and mulch practices in sub-plots. The base crop was taken mustard, while chickpea and lentil were tried as intercrops. Mustard variety "Pitambari", chickpea variety "Awrodhi" and lentil variety "K-75" were sown in the experiment. An uniform dose of $20 \mathrm{~kg} \mathrm{~N}+40 \mathrm{~kg} \mathrm{P}_{2} \mathrm{O}_{5} \mathrm{ha}^{-1}$ in sole chickpea and lentil as well as $60 \mathrm{~kg} \mathrm{~N}+30 \mathrm{~kg} \mathrm{P}_{2} \mathrm{O}_{5}+$ $30 \mathrm{~kg} \mathrm{~K} \mathrm{~K}_{2} \mathrm{O} \mathrm{ha}^{-1}$ in sole mustard crop. In intercroppings, each crop was fertilized as same rates but on the basis of actual area sown under component crops. The fertilizers were applied row-wise. Seed for sowing was used @ $5 \mathrm{~kg} \mathrm{ha}^{-1}$ of mustard, $80 \mathrm{~kg} \mathrm{ha}^{-1}$ of chickpea and $50 \mathrm{~kg} \mathrm{ha}^{-1}$ of lentil in sole cropping. Recommended package of cultural operations was followed. The crops were sown on October 30 and November 01 in first and second year, respectively. Sowing was followed by light planking. The lentil crop was harvested on March 07 and 05, mustard on March 10 and 07 as well as chickpea on March 24 and 20 during 2016-17 and 201718 , respectively. At sowing time, available soil moisture in $100 \mathrm{~cm}$ soil profile was 270.3 and 275.6 mm during 2016-17 and 2017-18, respectively. Total rainfall during crop period was 28.8 and $5.40 \mathrm{~mm}$ during first and second year, respectively.
Water use efficiency of the crop was calculated by the method described by Viets (1962). Mustard equivalent seed yield was worked out by converting the yield of chickpea and lentil into mustard yield on the basis of prevailing market price. The economics of various treatments were computed on the basis of prevailing market price of produce and agro-inputs.

\section{Results and Discussion}

\section{Seed yield of component crops}

Seed yield of both the intercropped crops reduced in association with mustard as compared to their sole crops (Table-1). Corresponding yield reduction was more under intercropping of mustard with chickpea and lentil additive series in both the years. All the cropping systems exhibited higher seed yield under dust mulch practice than no dust mulch plot during both the years.

\section{Mustard equivalent seed yield}

Mustard equivalent seed yield was recorded significantly highest under additive intercropping of mustard + chickpea $(1+1)$ during both the years (Table-2) may be attributed to its more adoptability scarce moisture condition by developing root system in the deeper soil layer as a result the maximum bifurcation of branches and higher seed production of both the crops. These results are similar with those of Lal et al., (2015) and Kour et al., (2015). Dust mulch practice recorded significantly higher mustard equivalent seed yield as compared to no dust mulch treatment during both the years. The higher seed yield observed with dust mulching plot might have been due to sufficient moisture conserved in soil which remaied for longer period, provided its life cycle successfully. These findings are substantiated by the findings of Katiyar et al., (2015) and Chavada et al., (2017). 
Table.1 Effect of cropping systems and mulches on seed yield of component crops (qha ${ }^{-1}$ )

\begin{tabular}{|c|c|c|c|}
\hline \multirow[t]{2}{*}{ Cropping systems } & \multicolumn{2}{|c|}{ Mulches } & \multirow[t]{2}{*}{ Mean } \\
\hline & $\begin{array}{l}\text { Without dust } \\
\text { mulch }\end{array}$ & $\begin{array}{l}\text { With dust } \\
\text { mulch }\end{array}$ & \\
\hline \multicolumn{4}{|c|}{ 2016-2017 } \\
\hline Sole mustard & 15.41 & 17.87 & 16.64 \\
\hline Sole chickpea & 16.10 & 18.36 & 17.23 \\
\hline Sole lentil & 9.55 & 10.75 & 10.15 \\
\hline Mustard + chickpea $(1+1)$-add. & $16.39(5.79)$ & $19.25(6.83)$ & $17.82(6.31)$ \\
\hline Mustard + chickpea (3:1)-repl. & $12.24(3.54)$ & $14.44(4.46)$ & $13.34(4.00)$ \\
\hline Mustard + chickpea (3:2)-repl. & $12.30(4.26)$ & $14.54(5.26)$ & $13.42(4.76)$ \\
\hline Mustard + lentil(1+1)-add. & $16.16(3.01)$ & $19.00(3.79)$ & $17.58(3.40)$ \\
\hline Mustard + lentil(3:1)-repl. & $12.21(2.19)$ & $14.29(2.65)$ & $13.25(2.42)$ \\
\hline Mustard + lentil(3:2)-repl. & $12.21(2.52)$ & $14.25(2.80)$ & $13.25(2.66)$ \\
\hline \multicolumn{4}{|c|}{ 2017-2018 } \\
\hline Sole mustard & 14.18 & 16.90 & 15.54 \\
\hline Sole chickpea & 14.52 & 17.07 & 15.79 \\
\hline Sole lentil & 8.44 & 9.96 & 9.20 \\
\hline Mustard + chickpea $(1+1)$-add. & $15.20(5.10)$ & $18.59(6.30)$ & $16.89(5.70)$ \\
\hline Mustard + chickpea (3:1)-repl. & $11.41(3.07)$ & $13.85(4.27)$ & $12.63(3.67)$ \\
\hline Mustard + chickpea (3:2)-repl. & $11.58(3.99)$ & $13.98(4.93)$ & $12.78(4.46)$ \\
\hline Mustard + lentil(1+1)-add. & $15.08(2.70)$ & $18.01(3.56)$ & $16.54(3.13)$ \\
\hline Mustard + lentil(3:1)-repl. & $11.28(1.96)$ & $13.58(2.52)$ & $12.43(2.24)$ \\
\hline Mustard + lentil(3:2)-repl. & $11.35(2.30)$ & $13.73(2.72)$ & $12.54(2.51)$ \\
\hline
\end{tabular}

Note: Figures in parentheses indicate yield of intercrops 
Table.2 Effect of cropping systems and mulches on mustard equivalent seed yield, land equivalent ratio, total water use and water use efficiency

\begin{tabular}{|c|c|c|c|c|c|c|c|c|}
\hline \multirow[t]{2}{*}{ Treatment } & \multicolumn{2}{|c|}{$\begin{array}{c}\text { Mustard equivalent } \\
\text { seed yield }\left(q \text { ha }^{-1}\right)\end{array}$} & \multicolumn{2}{|c|}{ Land equivalent ratio } & \multicolumn{2}{|c|}{ Total water use (mm) } & \multicolumn{2}{|c|}{ 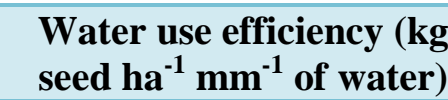 } \\
\hline & $2016-17$ & $2017-18$ & $2016-17$ & $2017-18$ & $2016-17$ & $2017-18$ & $2016-17$ & $2017-18$ \\
\hline \multicolumn{9}{|l|}{ Cropping systems } \\
\hline Sole mustard & 16.64 & 15.54 & 1.00 & 1.00 & 268.3 & 247.4 & 6.20 & 6.28 \\
\hline Sole chickpea & 18.62 & 17.37 & 1.00 & 1.00 & 212.8 & 198.0 & 8.75 & 8.78 \\
\hline Sole lentil & 10.84 & 9.77 & 1.00 & 1.00 & 204.9 & 183.3 & 5.29 & 5.33 \\
\hline Mustard + chickpea $(1+1)$-add. & 24.64 & 23.16 & 1.43 & 1.45 & 277.8 & 260.3 & 8.87 & 8.90 \\
\hline Mustard + chickpea(3:1)-repl. & 17.66 & 16.67 & 1.03 & 1.04 & 243.3 & 227.2 & 7.26 & 7.35 \\
\hline Mustard + chickpea(3:2)-repl. & 18.56 & 17.68 & 1.08 & 1.11 & 247.7 & 231.2 & 7.50 & 7.66 \\
\hline Mustard + lentil $(1+1)$-add. & 21.21 & 19.87 & 1.38 & 1.41 & 273.5 & 254.4 & 7.76 & 7.81 \\
\hline Mustard + lentil(3:1)-repl. & 15.83 & 14.81 & 1.03 & 1.04 & 241.6 & 225.1 & 6.55 & 6.58 \\
\hline Mustard + lentil(3:2)-repl. & 16.07 & 15.20 & 1.05 & 1.08 & 243.8 & 228.5 & 6.59 & 6.66 \\
\hline $\mathrm{SE}(\mathrm{d})$ & 0.86 & 0.80 & 0.06 & 0.06 & - & - & - & - \\
\hline $\mathrm{CD}(\mathrm{P}=\mathbf{0 . 0 5})$ & 1.82 & 1.70 & 0.13 & 0.13 & - & - & - & - \\
\hline \multicolumn{9}{|l|}{ Mulches } \\
\hline Without dust mulch & 16.38 & 15.11 & 1.10 & 1.11 & 248.1 & 230.6 & 6.57 & 6.51 \\
\hline With dust mulch & 19.19 & 18.24 & 1.12 & 1.14 & 243.8 & 226.1 & 7.83 & 8.02 \\
\hline SE (d) & 0.46 & 0.44 & 0.05 & 0.06 & - & - & - & - \\
\hline $\mathrm{CD}(\mathrm{P}=\mathbf{0 . 0 5})$ & 1.00 & 0.92 & NS & NS & - & - & - & - \\
\hline Minimum support price: & $2016-17$ & $2017-18$ & & & & & & \\
\hline Mustard seed @ Rs & $3700 \mathrm{q}^{-1}$ & $4000 \mathrm{q}^{-1}$ & & & & & & \\
\hline Chickpea seed@ Rs & $4000 \mathrm{q}^{-1}$ & $4400 \mathrm{q}^{-1}$ & & & & & & \\
\hline Lentil seed @ Rs & $3950 q^{-1}$ & $4250 q^{-1}$ & & & & & & \\
\hline Minimum support price: & 2016-17 & $2017-18$ & & & & & & \\
\hline Mustard seed@ Rs & $3700 \mathrm{q}^{-1}$ & $4000 \mathrm{q}^{-1}$ & & & & & & \\
\hline Chickpea seed@Rs & $4000 \mathrm{q}^{-1}$ & $4400 \mathrm{q}^{-1}$ & & & & & & \\
\hline Lentil seed@Rs & $3950 q^{-1}$ & $4250 \mathrm{q}^{-1}$ & & & & & & \\
\hline
\end{tabular}


Table.3 Effect of cropping systems and mulches on weed development at maturity, net return and benefit : cost ratio

\begin{tabular}{|c|c|c|c|c|c|c|c|c|}
\hline \multirow[t]{2}{*}{ Treatment } & \multicolumn{2}{|c|}{$\begin{array}{c}\text { Number of weeds }\left(\mathrm{m}^{-2}\right) \\
\text { at maturity }\end{array}$} & \multicolumn{2}{|c|}{$\begin{array}{l}\text { Dry weight of weeds } \\
\left(\mathrm{gm}^{-2}\right)\end{array}$} & \multicolumn{2}{|c|}{ Net return $\left(\right.$ Rsha $\left.^{-1}\right)$} & \multicolumn{2}{|c|}{ Benefit : Cost ratio } \\
\hline & 2016-17 & $2017-18$ & 2016-17 & $2017-18$ & 2016-17 & $2017-18$ & 2016-17 & $2017-18$ \\
\hline \multicolumn{9}{|l|}{ Cropping systems } \\
\hline Sole mustard & 271 & 263 & 137.7 & 135.3 & 32085 & 32746 & 1.96 & 1.96 \\
\hline Sole chickpea & 275 & 264 & 139.0 & 137.6 & 37921 & 34792 & 2.06 & 1.86 \\
\hline Sole lentil & 279 & 271 & 141.0 & 139.4 & 10624 & 3948 & 1.33 & 1.10 \\
\hline Mustard + chickpea $(1+1)$-add. & 229 & 218 & 124.4 & 122.2 & 53404 & 54557 & 2.22 & 2.21 \\
\hline Mustard + chickpea (3:1)-repl. & 251 & 239 & 129.9 & 128.9 & 34110 & 34608 & 1.96 & 1.93 \\
\hline Mustard + chickpea (3:2)-repl. & 244 & 229 & 127.6 & 125.9 & 37112 & 37441 & 2.02 & 1.96 \\
\hline Mustard + lentil (1+1)-add. & 238 & 221 & 126.5 & 124.7 & 43527 & 41955 & 2.09 & 1.97 \\
\hline Mustard + lentil (3:1)-repl. & 253 & 244 & 130.9 & 129.9 & 27741 & 27105 & 1.80 & 1.74 \\
\hline Mustard + lentil (3:2)-repl. & 248 & 233 & 128.8 & 127.0 & 28281 & 27508 & 1.81 & 1.72 \\
\hline \multicolumn{9}{|l|}{ Mulches } \\
\hline Without dust mulch & 303 & 292 & 141.9 & 140.7 & 31956 & 30284 & 1.98 & 1.87 \\
\hline With dust mulch & 205 & 192 & 121.5 & 119.5 & 35778 & 35197 & 1.89 & 1.81 \\
\hline
\end{tabular}




\section{Land equivalent ratio}

Land equivalent ratio was found highest under additive intercropping of mustard + chickpea $(1+1)$ during both the years (Table2) might be attributed to full yield of mustard and additional yield of intercrop. Similar was the findings of Kour et al., (2015). Dust mulch practice produce higher land equivalent ratio over no dust mulch treatment during both the years. Better utilization of land and growth resources by crops in dust mulch practice.

\section{Total water use and water use efficiency}

Total water use was estimated highest under additive intercropping of mustard + chickpea $(1+1)$ than other cropping systems during both the years (Table-2). It might be attributed to highest plant density per unit area which required more soil moisture for growth and development of crop plants. Mustard + chickpea (1+1) additive intercropping registered highest water use efficiency might be attributed to highest mustard equivalent seed yield. These results are in consonance with the findings of Rajvanshi (2013). Dust mulch practice of moisture conservation recorded lower total water use and higher water use efficiency as composed to no dust much treatment during both the years. Higher water use efficiency recorded by crops grown under dust mulching treatment might have been due to eradication of weeds, more pulverise surface soil resulting less evaporation and transpiration loss of water through weeds which in turn made it possible to utilize moisture by the crops more efficiently over no dust mulch practice. These results may also be supported by the findings of Yadav et al., (2011).

\section{Weed development}

The highest number of weeds $\left(\mathrm{m}^{-2}\right)$ and their dry weight were recorded at maturity time under sole croppings during both the years (Table-3). Moreover, these parameters of weeds under replacement intercroppings showed almost similar pattern with slight variation under intermediate group, but additive intercroppings proved to be the lowest group during 2016-17 and 2017-18 might be due to mustard shading and other adverse effects on weeds. Dust mulch as a practice of moisture conservation brought out decreased number of weeds $\left(\mathrm{m}^{-2}\right)$ and their dry weight over no dust mulch practice during both the years. The decrease in number of weeds $\left(\mathrm{m}^{-2}\right)$ and their dry weight under dust mulching practice might be due to repeated soil manipulation that creates unfavourable environment for weed seedlings, resulting slow pace of growth of first flush of weeds at 25 DAS thereafter the emergence of new flushes of weeds could not attain full growth under the shade of crop plants.

\section{Economics}

Net return and $\mathrm{B}: \mathrm{C}$ ratio were highest under additive intercropping of mustard + chickpea $(1+1)$ during both the years (Table-3). It might be attributed to highest mustard equivalent seed yield. These results are substantiated by the findings of Rajvanshi (2013) and Kour et al., (2015). Dust mulching exhibited higher net return as compared to no dust mulch treatment. However, this treatment was failed to exhibit superiority in B:C ratio over no dust mulching plot due to additional cost of dust mulch formation.

\section{References}

Chavada, J. N., Patel, C.K., Patel, S.B., Panchal, P. P. and Patel, G.N. (2017). Weed management in chickpea (Cicer arietinum L.) under North Gujarat conditions. International Journal of Science, Environment and Technology, 6 (3): 2017-2018

Das,S., Nandini Devi, K., Ashokpam, H.S., 
Hungdin, J.L. and Longjam, M. (2017). Chickpea (Cicer arietinum L.)-based intercropping system with rapeseed (Brassica napus L.) on growth, yield and competition indices. Environment and Ecology, 35 (1B): 427-430.

Hasan, G.N., Khan, M.H., Islam, M.M., Khan, M.S.I., Chakraborti, P., Akter, R. and Islam, M.R. (2018). Performance of chickpea (Cicer arietinum) and mustard (Brassica campestris) as a mixed crop in the coastal region of Bangladesh. International Journal of Agronomy and Agricultural Research, 13(2):43-49.

Katiyar, A.K., Uttam, S.K., Awasthi, U.D. and Rajput, P.K. (2015).Effect of moisture conservation practices on mustard based intercropping system with lentil under rainfed condition. Abstract: National Seminar on Managing Crop Productivity for Food Security in Changing Climate Scenario, held at Janta College, Bakewar, Etawah (U.P.) from March 28-29, pp.119.

Kour, R., Sharma, B.C., Anil Kumar and Sharma, N. (2015).Yield analysis of chickpea (Cicer arietinum) + Indian mustard (Brassica juncea) intercropping system through computation of intercropping indices. Indian Journal of Agronomy, 60(3): 281-385.

Lal, B., Rana, K.S., Gautam, P., Rana, D.S., Shivay, Y.S., Meena, B.P., Meena, R.K. and Singh, P. (2015). Ethiopian mustard- chickpea intercropping system is a viable option for yield advantage in dryland condition of North India - PartII. Proc. National Academy of Sciences, pp. 518-527.

Meena, H. and Kumhar, B. L. (2017). Production potential of gram-based intercropping systems under rainfed conditions. Advance Research Journal of Crop Improvement, 8(1):95-98.

Rajvanshi, J.K. (2013). Production potential of mustard (Brassica juncea. L.) based intercropping systems under rainfed condition. M.Sc. (Ag.) Thesis, Department of Soil Conservation and Water Management, C.S. Azad University of Agriculture and Technology, Kanpur.

Viets, F.G. (1962). Fertilizers and efficient use of water. Advances in Agronomy, 14:223-261.

Yadav, P.K., Singh, S.P., Dohare, A.P.S. and Singh, S. (2018).Phosphorus requirement in chickpea (Cicer arietinum) + Indian mustard (Brassica juncea) intercropping system under rainfed condition of Bundelkhand (U.P.). International Journal of Current Microbiology and Applied Sciences, 7: $3122-3127$.

Yadav, P.N., Uttam, S.K., Singh, R.P. and Kaushal Kumar (2011). Effect of fertilizer and moisture conservation on productivity, economics and water use efficiency of rainfed mustard (Brassica juncea). Current Advances in Agricultural Sciences, 3(2): 108-111.

\section{How to cite this article:}

Sumit Raj and Uttam, S.K. 2020. Production Potential and Economic Feasibility of Mustard Based Intercropping System with Chickpea and Lentil Crops under Rainfed Condition. Int.J.Curr.Microbiol.App.Sci. 9(11): 1819-1825. doi: https://doi.org/10.20546/ijcmas.2020.911.215 